\title{
ÇATIŞAN İKİ DÜNYA TASAVVURU VE RADİKAL ÖRGÜTLER ARASINDAKİ İLISSKI
}

\section{Uğur PEKTAȘ*}

\section{ÖZET}

11 Eylül saldırılarından sonra küresel terörizm ve İslam arasında nasıl bir ilişki olduğuna dair pek çok araştırma yapılmıştır. Bu çalışmada söz konusu araştırmalarda sıklıkla ele alınan Darul İslam-DarulHarb kavramları ile radikal örgütler arasındaki ilişki ele alınacaktır. Bu doğrultuda ilk olarak Darul İslam-DarulHarb düzen tasavvuru ele alınacaktır. İkinci olarak, Darul İslam-DarulHarb düzen tasavvuru ile Vestfalyan düzen arasındaki çatışmanın nedenleri ortaya konacaktır. Üçüncü olarak, terörizm ve küresel terörizm kavramlarına ilişkin tanım sorunu ele alınacaktır. Son olarak, Darul İslam ve Vestfalyan düzen tasavvurları üzerinden radikal örgütlerin uluslararası sistemdeki durumu analiz edilecektir. Çalışmada, radikal örgütlerin Soğuk Savaş sonrası uluslararası sistem için büyük bir tehdit olarak görülmesinin temel nedenini, söz konusu örgütlerin benimsediği Darul İslam-DarulHarb düzen tasavvurunun modern devletler sisteminin temel ilkelerine ve işleyişine meydan okuması olduğu varsayılmaktadır.

Anahtar Kelimeler: Darul İslam-DarulHarb, Vestfalyan düzen, radikal örgütler.

JEL Kodlari: F50, F52, N30.

*Niğde Üniversitesi Siyaset Bilimi ve Uluslararası İlişkiler Bölümü, Araştırma Görevlisi.e-mail: aras_kura42@hotmail.com 


\section{RELATION BETWEEN TWO CONFLICTING WORLD VISIONS AND RADICAL ORGANIZATIONS} ABSTRACT

After September 11 attacks, a lot of academic research has been made about what kind of relation there is between global terrorism and religion of Islam. In this study, the relation between radical organizations and Darul Islam-Darul Harb (Country of Islam-Country of War) world vision which is frequently studied a forementioned works will be handled. In this respect firstly, Darul Islam-Darul Harb world vision will be examined. Secondly, reasons of disaggrement between two conflicting world vision -Darul İslam and Westphalian order- will be put forward. Thirdly, problem of making definition about notions of terrorism and global terrorism will be discussed. And finally, state of radical organizations in international system will be handled in the context of Darul Islam and Westphalian order. In this research, the main reason of why radical organizations seen as a big threatto post-Cold War international system will be assumed that radical organizations challenge ordering principles of modern state system and its functioning.

Keywords: Darul İslam-DarulHarb, Wetphalianorder, radicalorganizations.

\section{GíRiş}

Günümüzde uluslararası terörizm ve şiddet ile İslam arasında nasıl bir bağ olduğuna dair tartışmalar yoğun bir şekilde yapılmaktadır. 11 Eylül saldırıları sonrası El Kaide, Taliban, Boko Haram ve IŞID gibi radikalörgütlerin faaliyetleri pek çok akademik çalışmaya konu olmaktadır. Söz konusu çalışmalar bu örgütlerin felsefesini, amaçlarını ve nasıl bu kadar etkili olabildiklerini açıklamaya çalışmaktadır. Söz konusu radikalörgütlerinsivil ve masum insanlara verdiği zararlar bir yana, onları büyük bir tehdit haline getiren esas unsur, mevcut uluslararası sistemin temellerini tehdit edecek bir söyleme sahip olmaları ve bunları gerçekleştirmeye uygun bir küresel ortamın bulunmasidir.

Modern devletler sisteminin temelinin Vestfalya Barış Antlaşmaları sonrasında atıldığına dair genel bir uzlaşma bulunmaktadır. Vestfalyandüzenin iki temel ilkesi devletlerin egemen eşitler olduğu ve birbirilerinin iç işlerine karışmamaları gerektiğidir. Bu sistem Batı Avrupa'da ortaya çıkmış ve zaman içinde çeşitli unsurların birleşimi ile küresel bir sistem haline gelmiştir. Vestfalyandüzen, küresel bir niteliğe bürünürken kendisine meydan okuyan diğer düzen tasavvurlarını da seçenek dış1 bırakmıştır. $\mathrm{Bu}$ düzen tasavvurlarından biri de bugün radikalörgütlerin benimsediği Darul İslamDarulHarbdüzenidir.

Darul İslam-DarulHarb düzeni, kendilerini İslam devleti olarak niteleyen devletlerin 8. asırdan itibaren diğer ülkelere yayılmak için kullandıkları bir düzen tasavvurudur. Bu düzende Müslüman yöneticilerin yönettiği ve İslam hukukun uygulandığı ülkeler Darul İslam (İslam ülkesi) olarak nitelenmektedir. Diğer ülkeler ise DarulHarb (Savaş ülkesi) olarak nitelenmektedir. Nihai hedef, Darul İslam'ın tüm yeryüzüne hâkim olmasıdır. Yani dünyanın tamamının İslam hukukunun uygulama alanı haline gelmesidir. Bu bakış açısı, Emeviler ve Abbasiler döneminden Osmanlı İmparatorluğu'nun Avrupa Devletler sisteminin bir parçası olarak kabul edildiği 1856 Kırım Savaşı sonuna dek kendilerini İslam ülkesi (Darul İslam) olarak niteleyen devletlerin temel söylemi olmuştur. Bir kısmı Osmanlı İmparatorluğu'nun dağılması sonucu, diğerleri de de-kolonizasyon süreci sonrasında bağımsızlık elde eden ve halkının çoğunluğu Müslüman olan devletlerin elitleri Vestfalyan sistemi benimsemiştir. Halifeliğin kaldırılması ve Türkiye Cumhuriyeti'nin kurulması ile Darul İslam düzenini savunan bir devlet kalmamıştır. Vestfalyandüzen, Soğuk Savaş'ın da sona ermesi ile rakipsiz kalmıştır. Ancak, çoğunluğu Müslüman olan devletlerin, sosyo-ekonomik ve siyasi açılardan vatandaşlarının 
beklentilerini karşılayamaması hatta meşru şiddet tekelini bile kaybetmeye başlaması Darul İslamDarulHarb düzenini benimseyen radikallerin ortaya çıkmasına ve geniş bir nüfuz alanı elde etmelerine ortam hazırlamıştır.

$\mathrm{Bu}$ doğrultuda söz konusu çalışmanın hipotezi, söz konusu radikallerinSoğuk Savaş sonrası uluslararası sistem için büyük bir tehdit olarak görülmesinin temel nedenini, bahsedilenradikal örgütlerin benimsediği Darul İslam-DarulHarb düzen tasavvurunun modern devletler sisteminin temel ilkelerine ve işleyişine meydan okuması olarak ele almaktadır.Bu doğrultuda çalışmanın ilk kısmında Darul İslam düzen tasavvuru genel hatlarıyla ele alınacaktır. Darul İslam kavramının ortaya çıkmasında belirleyici olan nesih kavramı ve bu kavramın uygulamada yol açtığ gelişmeler ele alınacaktır. Çalışmanın ikinci kısmında Darul İslam sistemi ile Vestfalyan devletler sistemi arasında mücadelenin nedenleri ve sonuçları ifade edilecektir. Üçüncü kısımda bu çalışma için önemli kavramlardan bir diğeri olan terörizm olgusuna ilişkin kavramsal bir çerçeve sunulacaktır. Son kısımda ve sonuç bölümünde ise 1990sonrası uluslararası gündemi işgal eden radikal terörist örgütlerDarul İslam ve Vestfalyan devletler sistemi üzerinden tartış1lacaktır.

\section{DARUL ÍSLAM-DARUL HARB SISTEMI}

Darul İslam-DarulHarb Sistemi, radikal örgütlerin eylemleri ve özellikle 11 Eylül saldırılarından sonra Batılı literatürde popüler olan kavramlardan birisidir. Küresel terörizmin nedenleri ele alan bir çalışmada veya spesifik bir küresel terörist örgütü ele alan çalışmalarda bu kavramlara bir şekilde yer verilmektedir. Çalışmanın bu kısmında Darul İslam düzen tasavvuru ele alınacaktır. Ama Darul İslam, Darul Harb ve Darul Sulh gibi kavramları anlayabilmek için öncelikle İslam'da hangi durumlarda savaşa başvurulmasına imkân verildiğine dair yaklaşımları ele almak gerekmektedir. Çünkü söz konusu kavramlar İslam'a göre haklı savaşa ilişkin yaklaşımlar ile doğrudan alakalıdır.

\subsection{Kuran'ı Kerim'e ve Fıkıhçılara Göre Savaşın Nedenleri}

İslam dininin anayasası olarak nitelenebilecek ve İslam'a dair diğer tüm kaynakların aykırılık teşkil edemeyeceği bir kitap olarak Kuran, haklı savaşı yani Müslümanların hangi durumlarda savaşa ${ }^{1}$ başvurmalarının meşru olduğu konusunu çeşitli ayetlerle düzenlemiştir. Kuran bir bütün olarak hermeneutik bağlamda incelendiğinde görülecektir ki savaşa iki durumda başvurulabilir. Birinci durum, Müslüman bir topluma yönelik saldırı eylemlerine karşılık olarak Müslümanların meşru müdafaa hakkına sahip olduğudur. Yani şiddete başvurulması durumunda ilk saldırıyı Müslümanlar değil düşman olarak nitelenen grup yapmalıdır.

$\mathrm{Bu}$ duruma ilişkin olarak Kuran'da çeşitli ayetler mevcuttur. Mümtehine suresinin 8. ve 9. ayetleri: "Allah, dini hususlarda sizinle savaşmamış ve yurtlarınızdan sizi çıkarmamış kimselere karşı iyilik etmekten ve adil davranmaktan sizi men etmez. Allah, adil davrananları sever. Allah, dini hususlarda sizinle savaşmış, yurtlarınızdan sizi çıkarmış ve çıkarılmanız için birbirleriyle

\footnotetext{
${ }^{1}$ Kuran'da savaş kavramına ilişkin olarak kıtal, harb ve cihad kelimeleri kullanılmaktadır. Bu kavramlar içerisinde cihad kavramının günümüzde daha sık tercih edildiği görülmektedir. Cihad kelimesi "çabalamak" ve "uğraşmak" gibi anlamlara sahiptir. İslam adına yapılan savaşlar mücadele ve çaba gerektirdiği için cihad kavramı daha çok tercih edilmektedir. (Taslaman, 2016: 33-34). Cihad kavramının manevi boyutu da vardır. Bir Müslümanın İslamiyet'e uygun bir yaşam sürmek için çabalaması veya dinini diğer insanlara tebliğ etmesi de cihad olarak nitelenebilir (Kissinger, 2014: 115).
} 
yardımlaşmış olanlarla dostluk kurmaktan sizi men eder. Onlarla dostluk kuranlar zalim kimselerdir." (Mevdûdi, 2004: 290).Nisa suresinin 90. ayeti: "Ancak sizinle aralarında antlaşma olan bir topluma sığınanlarla, kendi toplumlarıyla yahut sizinle savaşma konusunda yürekleri yetersiz kalıp da size gelenlere dokunmayın. Allah dileseydi onları elbette sizin üstünüze salardı, onlar da sizinle mutlaka savaşırlardı. O halde, sizden uzak durur, sizinle savaşmaz, size barış eli uzatırlarsa, artık Allah size, üzerlerine gitmek için bir yol vermemiştir." (Öztürk, 2016: 92). Ve Enfal suresinin 61. ayeti: "Eğer barışa eğilim gösterirlerse sen de buna yanaş ve Allah'a tevekkül et! Çünkü $O$, en iyi işitenin, en iyi bilenin ta kendisidir" (Öztürk, 2016: 170).

Kuran'da savaşa cevaz veren ikinci durum ise, günümüzde uluslararası hukukta insani müdahale kavramına benzer bir niteliğe sahiptir. Yani, Müslüman bir toplum (buna A diyelim) gayri Müslim olan diğer bir toplum (buna B diyelim) tarafından saldırıya uğramaları halinde diğer Müslüman toplumdan (buna da $\mathrm{C}$ ) diyelim aralarındaki din bağından ötürü yardım istemesi durumunda C'nin A'ya yardım etmesi gerekmektedir. Burada bir istisna da eklenmiştir. B ve C birbirlerine saldırmayacaklarına dair aralarında bir anlaşma yaptılarsa C A'ya yardım edemez. Kuran böylece gayri Müslim ile dahi olsa yapılan bir anlaşmaya ahde vefanın iki Müslüman toplum arasındaki din bağından bile daha önemli olduğunu ortaya koymaktadır. Enfal suresinin 72. ayeti bu durumu şöyle ifade etmektedir: "Gerçeği onaylayanlar, ALLAH yolunda göç edenler, mallarıyla ve canlarıyla cihat edenler ve onları barındırıp onlara yardım edenler birbirlerinin dostudur. Gerçeği onayladığı halde sizinle birlikte göç etmeyenler göç edinceye kadar onlardan sorumlu değilsiniz. Ancak onlar, din bağından ötürü sizden yardım isterlerse, aranızda anlaşma bulunan bir topluma karşı olmaması koşuluyla kendilerine yardım etmelisiniz. ALLAH yaptıklarınızı görendir." (Yüksel, 2014: 172).

İslam Peygamberine ve Müslümanlara İslamiyet'in ilk yıllarında Mekkeliler tarafından bask1 ve zulüm uygulanmıştır. Baskının yoğunluğu artınca Hz. Muhammed Müslümanların Hicret etmelerini istemiştir. Müslümanların bir kısmı Habeşistan'a diğerleri de Medine'ye göç ettiler. Ancak Mekkelilerin Müslümanlara yönelik uyguladığı şiddet ve baskı devam edince Mekkelilerle savaşılması yönünde ayetlerin de vahiy edilmesi ile Medine site devleti Mekkeliler ile bir dizi savaş yapmıştır. İslam'ın Hz. Muhammed ve ilk dört halife döneminde yapılan savaşlar meşru müdafaaya dayandırılarak yapılmıştır. İslam'ın birinci asrında, sadece Mekkeliler değil, İslam'ın hızla yayılmasını kendi imparatorlukları için tehdit olarak gören Bizans ve Sasani İmparatorlukları ve onlara bağlı devletler de söz konusu durumu önlemek için İslam Devletine saldırmışlardır. (Özel, 2014: 45-46 ve 50-52) Yani İslam'ın ilk asrında yapılan söz konusu savaşlar toprak ve ganimet için değil meşru müdafaa için yapılmıştır. Bu savaşlar sonucunda toprak ve ganimet elde edilmiştir. Ancak savaşa başvurulmasının sebepleri yeni topraklar fethetme ve ganimet elde etme değildi.

Kuran'da savaşa hangi koşullarda imkân verildiğine ilişkin ayetler dikkate alındığında şöyle bir çelişki ortaya çıkmaktadır. Emeviler Devleti, Abbasiler devleti, Osmanlı İmparatorluğu ve bu devletler dışında kendisini İslam devleti olarak niteleyen devletlerin yaptığı savaşların içinde meşru müdafaaya ilişkin savaşlar olduğu gibi, saldırı amaçlı savaşlar da görülmektedir. Kuran'ın haklı savaşa ilişkin söz konusu ayetleri; toprak, ganimet, şan veya şöhret gibisaiklerle yapılan savaşları meşru olarak kabul etmemektedir. Söz konusu sınırlamayı aşmak için çeşitli mezheplerden İslam hukukçuları 
nesih kavramına başvurmuş ve Kuran'ın haklı savaşa ilişkin kısıtlamalarını bir şekilde aşmayı becerebilmişlerdir. Nesih kavramının Kuran'da savaşa ilişkin ayetlerin hükümlerini esnetmesi ise Darul İslam ve DarulHarb şeklinde dünyanın ikiye ayrılmasına ortam hazırlamıştır. Bu doğrultuda Darul İslam-DarulHarb dünya tasavvurunu anlayabilmek için öncelikle nesih ve mansuh kavramlarını açıklamak gerekmektedir.

\subsection{Darul İslam-DarulHarb Ayrımının Kökeni: Nesih-Mansuh Uygulaması}

Nesih kelimesi, bir kişinin daha önce yazdığı bir metni başka bir kitaba veya kitap benzeri bir şeye aktarırken önceki yazdıklarının bir kısmını çıkarmasını, bir kısmını değiştirmesini ve kalanını da aynen aktarması anlamına gelmektedir. Bu bağlamda Allah, İncil ve Tevrat gibi Kuran'dan önceki kutsal metinlerde yer alan hükümlerin bir kısmını Kuran'a eklememiş, bir kısmının hükmünü hafifleterek Kuran'a eklemiş, kalan kısımlara ilişkin hükümleri de Kuran'a aynen aktarmıştır. Hükmü değiştirilen veya kaldırılan kısma mensuh, mensuhun yerine geçene ise nesih adı verilmektedir (Bayındır, 2014: 445). Kuran'da nesih kavramının varlığı Bakara suresinin 106. ayetinde açıklanmıştır: "Biz, neshettiğimiz veya unutturduğumuz bir ayetin yerine ya daha iyisini ya da en azından benzerini getiririz. Allah'ın her şeye kadir olduğunu bilmez misin?" (Mevdûdi, 2004: 36).

Allah, İslam'dan önceki dinlere ait çoğu hükmü Kuran'a dâhil etmiştir. Bu durumu Kuran'ın 42. suresinin 13. ayeti ifade etmektedir. "O, Nuh'a emrettiği din sistemini sizin için de (din olarak) belirlemiştir. Ve ey Muhammed! İbrahim'e, Musa'ya ve İsa'ya ısrarlı bir şekilde: 'Bu dini ayakta tutun ve onda tefrikaya düşmeyin.' diye talimat verdiğimiz o sistemi şimdi sana vahiy yoluyla gönderdik..." (Mevdûdi, 2004: 255-6). Allah'ın Hz. Muhammed'den önceki peygamberler aracılığıyla belirttiği bazı hükümler Kuran'da değiştirilerek hafifletilmiş şekliyle Kuran'a eklenmiştir. Bu duruma örnek olarak İncil ve Tevrat'ta zina eden erkek ve kadına yönelik uygulan recm yani taşlayarak öldürme cezasının Kuran'da hafifletilerek düzenlenmesi örnek gösterilebilir. Konuya ilişkin ayette şöyle ifade edilmektedir: "Zina eden kadın ve zina eden erkeğin her birine yüz değnek vurun. Eğer Allah Teâlâ'ya ve ahiret gününe iman ediyorsanız, Allah'ın dinini uygulama hususunda onlara karşı acıma duygusuna kapılmayın..." (Mevdûdi, 2004: 192). Kuran, İncil ve Tevrat'ta yer alan bazı hükümleri ise içermemiştir (Bayındır, 2014: 446). Maide suresinin 15. ayetinde "Ey Ehlikitap! Resulümüz size geldi. Kitaptan saklamış olduklarınızın çoğunu size ayan beyan açıklıyor; çoğunu da dokunmadan bırakıyor. Şu bir gerçek ki, size Allah'tan bir 1ş1k ve söylemek istediğini apaçık söyleyen bir kitap gelmiştir." (Öztürk, 2016: 108). Bu ayette kitap ehli olarak nitelenen Yahudi ve Hiristiyanlara vahiy edilen bazı hükümlerin Kuran'da ifşa edildiği, bir kısmının ise Kuran'a dâhil edilmediği anlaşılmaktadır.

Yukarıda da ifade edildiği gibi Kuran'da sadece saldırgana karşı savaş yapılmasına cevaz verilmektedir. Hanefi mezhebinin İslam hukukçuları, bazı Hanbelî ve Maliki mezhebine bağlı hukukçular da bu görüştedir. Ancak Şafi mezhebinin İslam hukukçuları ile diğer Hanbelî ve Maliki İslam hukukçuları oldukça farklı bir görüşe sahiptir. Buna göre, İslam dini dışında bir dine mensup olmak yani gayri Müslimlik söz konusu toplum için savaş sebebi olarak yeterli görülmüştür. Şafi hukukçularsöz konusu argümanlarınıTevbe süresinin 5. ayeti ile temellendirmeyeçalışmışlardır (Taslaman, 2016: 35): "O haram aylar çıktı̆̆ında artık müşrikleri, kendilerini bulduğunuz yerde öldürün. Yakalayın onları, kuşatın onları, tüm geçit noktalarını tıkayın onların. Bunun ardından tövbe 
eder, namazı/duayı yerine getirir, zekâtı verirlerse, yollarını açın onların. Kesin olan şu ki, AllahGafur'dur, Rahim'dir."(Öztürk, 2016: 173). Nesih kavramını kullanan İslam hukukçularının bakış açısına göre Kuran'da Müslüman olmayanlara yönelik savaş olgusu aşamalar halinde gelişmiştir. Onlara göre, Hicretten önceki dönemde Müslümanlara gayri Müslimler ile savaşmak haramdı. Hicretten sonra Müslümanlara savaş açan gayri Müslimlere/müşriklere karşı savaşılması hükmü geldi. Daha sonra ise tüm gayri Müslimlere/müşriklere karş1 savaşmak farz kılındı (Kutup vd., 2014: 30; Kutub, 2012: 207-210). Nesih kavramını Kuran ayetleri arasında uygulayanlar Kuran ayetlerinin 22 yıl boyunca Hz. Muhammed'e vahiy edildiğini, dolayısıyla savaşa ilişkin ayetlerin de bu süre zarfında değişime uğradığını ifade etmektedir. Onlara göre, savaşa ilişkin en son vahiy edilen ayetler öncekilerin hükmünü ortadan kaldırmaktadır. Bu bakış açısına göre ise Müslümanların gayri Müslimler ile savaşması için Müslüman olmamak tek başına yeterli bir sebep haline gelmektedir.

Nesih kavramını Kuran'a uygulayanlar bazen "sahih" olduğunu iddia ettikleri hadisler ile bile Kuran ayetlerini nesih etmeye çalışmışlardır. Bu duruma örnek olarak Hz. Muhammed'in şu sözü söylediği iddia edilmektedir: "İnsanlarla, Allah'tan başka ilah yoktur demelerine kadar savaşmakla emrolundum." (Özel, 2014: 58). Nesih kavramını Kuran ayetlerine uygulayanlar pek çok ayet ve hadisi kullanarak iddialarını güçlendirmeye çalışmışlardır. Böylece meşru müdafaaya yönelik ayetler,Tevbe suresinin 5. ayeti gibi ayetler ${ }^{2}$ ve çeşitli hadisler kullanılarak nesh edilmiştir yani hükmü ortadan kaldırılmıştır. Ancak nesih-mansuh tartışmasında karşı tarafı savunanlara göre nesih kavramının Kuran'ın ayetleri arasında uygulanabilmesine dair bir Kuran ayeti yoktur. Şafiler gibi bir bakış açısına sahip olanlar Tevbe suresinin 5. ayetindeki müşrik kavramın tüm gayri Müslimleri içerecek şekilde yorumlamıştır. Karşıt görüşte olanlar ise, söz konusu ayette bahsedilen müşriklerin Müslümanlara savaş açan ve aralarındaki anlaşmayı bozan kişileri nitelediğini yani tüm müşrikleri/ gayri Müslimleri kapsamadığını vurgulamaktadır. Onlara göre, bir meseleye ilişkin Kuran genel olarak incelendiğinde önceki ve sonraki ayetlere de bakılarak hermeneutik bir bakışla yorumlanmalıdır (Taslaman, 2016; Özel, 2014). Kuran'daki bir ayet cımbızla çekilip bağlamından ayrı bir şekilde ele alınmamalıdır. Gayri Müslim olmayı savaş sebebi olarak yeterli gören hadislere ilişkin olarak ise Abdülaziz Bayındır, hiçbir hadisin Kuran'a aykırı olamayacağı çünkü hadislerin Kuran'a tabi olduğunu belirtmektedir (Bayındır, 2014: 449). Nesih-mansuh kavramlarının Kuran ayetleri arasında uygulanıp uygulanamayacağı veya nesih-mansuh tartışmasında hangi tarafın haklı olduğuna dair bir inceleme bu çalışmanın kapsamı içerisinde değildir. Bu çalışmada nesih kavramının uygulamada yol açtığı gelişmeler yaniDarul İslam ve DarulHarb kavramları ile bu kavramların yol açtığı gelişmeler ele alınacaktır.

Dar kelimesi sözlükte ev, bir topluluğun konakladığı yer anlamına gelmektedir. İslam hukukunda ise dar kelimesi ile İslam yönetiminin uygulandığ 1 ülke veya diğer dinlerin yönetimlerin uygulandığı ülke anlamında kullanılmaktadır. Bu tanıma göre bir ülkenin Müslümanlara ya da gayri Müslimlere atıfta bulunarak ayrılmasında esas ölçüt söz konusu ülkeyi kimlerin yönettiğidir. Ahmet Özel'e göre İslam hukukçuları, bir devletin hükümranlığında bulunan yerleri tespit etmek, söz konusu

\footnotetext{
${ }^{2}$ Kuran'da nesih kavramını Kuran ayetleri arasında da uygulayanlar, Müslüman olmayan herkese sadece bu nitelikleri yüzünden savaş açılabileceğine ilişkin iddialarını Kuran'daki çeşitli ayetlere göndermeler yaparak savunmuşlardır. Bu ayetlere örnek olarak Bakara suresinin 191. ayeti, Tevbe suresinin 29, 36 ve 123. ayetleri ve Enfal suresinin 65. ayeti gösterilebilir (Özel, 2014: 51-52).
} 
ülkede yaşayan toplum ile diğer devletlerin toplumları arasındaki ilişkileri düzenlemek vb. kaygılarla dünyayı ikiye ayırmışlardır: Darul İslam ve DarulHarb. İslam hukukunun uygulandığı ve yöneticilerinin Müslüman olduğu ülkeler Darul İslam olarak, Darul İslam'a dâhil olmayan diğer yerler ise DarulHarb olarak nitelenmiştir (Özel, 2012: 43-44). Darul İslam ve DarulHarb ayrımında Özel'in vurguladığı hususlar da etkili olmakla birlikte dünyayı böyle bir mantıkla ikiye ayırmayı tam olarak açıklayamamaktadır. İlk olarak yukarıda da ifade edildiği gibi dünyayı savaş mantığına göre ikiye ayırmanın temel nedeni, gayri Müslim olmayı tek başına savaş sebebi olarak yeterli gören fikıhçıların bakış açısıdır. ${ }^{3}$ Böyle bir bakış açısının savaşı süreklilik arz eden bir olgu olarak görmesi doğaldır. Dünyayı Müslümanların ve gayri Müslimlerin sürekli olarak savaş içinde olduğu bir yer olarak tahayyül edince gayri Müslimlerin yaşadığı yerler kaçınılmaz olarak DarulHarb yani savaş ülkesi haline gelmektedir. İkinci olarak, haklı savaşa ilişkin Hz. Muhammed ve ilk dört halife dönemi ile sonraki dönemler arasında farklılıklar olduğu görülmektedir. İlk dört halife döneminin sonuna kadar İslam devleti sadece meşru müdafaa amacıyla savaşmıştır. İslam'ın yayılması açısından en kritik dönemde bile ne Hz. Muhammed ne de ilk dört halife DarulHarb kavramını kullanmamıştır. Üstelik Kuran'da hatta hadislerde bile Darul İslam ve DarulHarb kavramları bulunmamaktadır. Söz konusu kavramlar bazı İslam hukukçularının icat etmiş olduğu kavramlardır.

Darul İslam ve DarulHarb kavramlarına ilişkin tartışmalarda sıklıkla Darul Sulh kavramı da ele alınmaktadır. Darul İslam-DarulHarb kavramlarını savunanlar söz konusu ayrımın sürekli bir savaşı ifade etmediğini belirtmektedir. Müslümanların gayri Müslimler ile olan ilişkilerinde sürekli bir savaş hali olmadığını, DarulSulhün (sulh veya dar anlamda barış, yani savaşın olmadığı ülke) de olduğunu vurgulamaktadır. Bu yaklaşıma göre, Darul İslam ve DarulHarb devletleri arasında anlaşmalar yoluyla iyi ilişkilerin kurulabileceği ve böyle ilişkilerin oluşturulduğu vurgulanmaktadır (Özel, 2014: 45). Ancak Darul Sulh kavramı Müslümanlar ve gayri Müslimler arasında eşitliğe dayalı bir ilişki kurulduğu anlamına gelmemektedir. Darul İslam ve DarulHarb arasında ara bir bölge olarak nitelenebilecek DarulSulhte gayri Müslim yöneticiler ülkelerini yönetebilmektedir, ancak bu durum Müslüman süzeranlığı altında gerçekleşmektedir. DarulSulhe örnek olarak Emevi Halifesi Muaviye ile Ermeni prensleri arasındaki ilişkiler örnek gösterilebilir. Ermeni prensler ile Müslümanlar, Ermeni prenslerin kendi topraklarında hükümranlık yapmalarına olanak sağlayan anlaşmalar yapmışlardır. Osmanlı İmparatorluğu da Balkanlardaki genişlemesi sırasında gayri Müslimler ile benzer anlaşmalar yapmışlardır (Lewis, 2011: 122-123). Görüldüğü gibi Darul Sulh olgusu bile savaşa ilişkin bir kavramdır ve ancak gayri Müslimler Müslüman yöneticilerin süzeranlığını kabul ettiğinde ortaya çıkabilmektedir.

Darul İslam-DarulHarb düzen tasavvuru hem Emevi Devleti ile başlayıp Osmanlı Devleti ile sona eren "İslam" devletleri silsilesi bağlamında hem de 1990 sonrası uluslararası ilişkilerde sıklıkla duyulan küresel terörizm olgusu bağlamında önem taşımaktadır. Bu düzen tasavvurunun karşılaştığı

\footnotetext{
${ }^{3}$ Bu bakış açısını savunan isimlerden SeyyidKutub'a göre, Müslümanlara cihad önce yasaktı, Hicretten sonra Müslümanlara saldıranlara karşı savaş emri geldi. Daha sonra ise bu sınırlama da kaldırıldı ve cihad için sadece Müslüman olmama yeterli bir sebep haline geldi. Kutub'a göre söz konusu gayri Müslimler böylece üç kategoriye ayrılmaktadır. Birinci grup zımmiler, yani Darul İslam'da yaşayan gayri Müslimlerdir. İkinci grupta kendisiyle anlaşma yapılan gayri Müslimler yer almaktadır. Üçüncü grupta ise harb edilen gayri Müslimler vardır (Kutub, 2012: 202).
} 
sistemler ile (Christendom ve Vestfalyan devletler sistemi) mücadelesi Orta Çağ'1 ve 1990 sonrası uluslararası ilişkileri derinden etkilemiştir.

\section{3. İKİ SISSTEM NEDEN ÇATIŞMAKTA?}

Nesih kavramının Kuran ayetlerine de uygulanması Müslümanlar ile gayri Müslimler arasında Thomas Hobbes'un (2013) tabiri ile sürekli bir savaş halinin ortaya çıkmasına yol açmıştır. Dünyayı bu şekilde tasavvur edince Darul İslam ve DarulHarb ayrımı kaçınılmaz bir hal almaktadır. Böyle bir dünya tasavvuru aslında yeni değildir. Hıristiyanlar da sağ yanağıma tokat vurursanız diğerini çeviririm diyecek kadar şiddete uzak bir peygamberin dininden Haçlı Seferlerini ortaya çıkartabilmişlerdir.Darul İslam'ın Avrupa'daki karşılığ 1 ise Christendom (Hristiyanlık ülkesi) olmuştur. Hilal ile Haçın 7. ve 17. yüzyıllar arasındaki mücadelesi bu bağlamda okunabilir. Hıristiyanlık da İslam gibi evrensel bir düzen tasavvuruna sahiptir. Bu iki rakip sistem arasındaki mücadele 7. yüzyılda başladı ve Westfalyan düzenin oluşumuna kadar devam etti. İslam ve Hıristiyanlık arasında Haçlı seferleri ve cihatlar, fetihler ve karşı fetihler (reconquest) birbirini takip etti (Lewis, 2003: 195-196) Söz konusu rekabet, Avrupa'da yeni bir düzen tasavvurunun ortaya çıkmasıyla farklı bir hal aldı. Avrupa'da Reform hareketlerinin tetiklediği mezhep anlaşmazlıkları 16. ve 17. yüzyıllarda Avrupa'da Kutsal Roma İmparatorluğu ve Papalık'akarşı Protestan prensler arasında bir dizi savaşa yol açmıştır. 1555 Augsburg Anlaşması ile her prense kendi hükümranlığında istediği mezhebi seçmesi hakk1 verildi. Ancak bu anlaşma kısa süreli bir barış getirdi. Taraflar 30 Yıl Savaşları olarak nitelenen 161848 y1lları arasında tekrar savaştılar. Savaşın sonunda imzalanan Münster ve Osnabrück Anlaşmaları ile modern devletler sisteminin temellerinin atıldığına dair genel bir uzlaşma vardır. Christendom'un yerini alan Vestfalyan düzen pek çok açıdan farklılık göstermektedir. ${ }^{4}$ Öncelikli olarak bu sistemde Kilisenin meşru şiddet tekeli elinden alınmış ve bağımsız devletlere verilmiştir. Christendom'da hiyerarşik bir yapı bulunmaktaydı. Hiyerarşinin tepesinde iki kılıç doktrinine uygun olarak dünyevi meselelerde Kutsal Roma İmparatoru, dini meselelerde ise Papa yer almaktaydı. Vestfalyan sistemde bu hiyerarşik yapı terk edilmiştir. Sistemi oluşturan devletler egemen eşitlik ilkesi ve birbirlerinin iç işlerine karışmamayı prensip olarak kabul etmişlerdir. Devletlerin egemen eşitliği ve birbirlerinin iç işlerine karışmama ilkeleri iki önemli sonuç yaratmıştır. Birincisi Vestfalyan sistemde devletlerin üstünde hiçbir üst otorite yoktur. Bu da sistemi anarşik yapmaktadır. İkincisi ise devletler birbirlerinin toprak bütünlüğüne saygı göstermeyi de taahhüt etmiş olmaktadır. Bu da devletin toprak bütünlügünün korunması genel ilkesini oluşturmuştur (Poggi, 2012;Gross, 1948).

Christendom,Vestfalyan sisteme dönüşmüş ve tarihsel süreç içerisinde bölgesel bir sistemden küresel bir sistem haline gelmiştir. Bu doğrultuda kendisiyle rekabet eden sistemleri tek tek ortadan kaldırmıştır. Çin İmparatorluğu ve Japon İmparatorluğu bunlardan bir kaçıdır. 20. yüzyıla kadar

\footnotetext{
${ }^{4}$ SeyyidKutub, Hıristiyan ülkesi (Christendom) ve Darül İslam'ın parçalanmasını Avrupa'daki Reformasyon ve ulusçuluk süreçleri ile açıklamaktadır. Ancak farklı bir perspektifle olaya bakmaktadır. Kutub'a göre Yahudiler Hıristiyanlığın parçalanması ve her bir devletin kendi ulusal kiliselerini kurmasına destek olarak kendilerine hareket alanı açmışlardır. Kutub'a göre aynı taktiği kullanan Hıristiyanlar da Müslümanları renklerine, dillerine ve uluslarına göre ayırarak İslam dünyasını parçalamışlardır (Kutub, 2012: 46-48). Kutub, Müslümanların modern bir cahiliye dönemini yaşadığını ifade edip onlara reçete sunmaktadır. Öncelikli olarak İslam hükümlerinin esas olduğu bir İslam devleti kurulmalıdır. Kutub'a göre Müslümanların çoğunlukta olduğu devletlerde bile Batılı devletlerin sistemi hâkimdir. Kutub bu devletleri İslam ve Müslümanlık sıfatlarını kullansalar bile İslami olarak kabul etmemektedir. Daha sonra bu İslam devleti en yakınındaki bölgelerdeki İslam dışı hükümlerle yönetilen devletleri sırayla alt etmelidir. Böylece İslam devleti dünyayı hâkimiyeti altına alacak ve yeryüzünün her yerinde İslami hükümler esas olacaktır. Kutub'un bakış açısında bu süreç sonucunda sadece Müslümanlar değil tüm insanlık huzura kavuşacak; çektiği sıkıntılardan ve uğradığı baskıdan kurtulacaktır (Kutub, 2012: 147 ve 206-211).
} 
Vestfalyan sisteme en büyük meydan okumayı ise Osmanlı İmparatorluğunun temsil ettiği Darul İslam düzen tasavvuru yapmıştır. Osmanlı İmparatorluğu gerek halifelik unvanı gerekse de sahip olduğu geniş toprak parçasıyla Vestfalyan düzenin parçaları olan Avrupalı devletler ile mücadele etmiştir. 1683 yılındaki İkinci Viyana Kuşatmasına kadar saldırı konumunda olan Osmanlı Devleti, bu kuşatmanın başarısızlığı ve Avrupalı kolonyal devletlerin de yükselişiyle birlikte savunmaya geçmiştir. Darul İslam'ın geri çekilişi ve Müslüman toplumların sırayla Avrupalıların egemenliği altına girmesiyle Darul İslam küçülmeye başlamıştır. Türkiye Cumhuriyetin kurulması ile Osmanlı İmparatorluğunun sona ermesi sonucunda Darul İslam düzen tasavvurunu savunacak bir devlet kalmamıştır (Kissinger, 2016: 111-163). Osmanlı Devletinden bağımsızlığını elde eden devletler Vestfalyan sistemin bir parçası haline geldiler. Çoğunluğunu Müslümanların oluşturduğu kolonyal devletler ise II. Dünya Savaşı sonrasında hızlanan de-kolonizayon süreci ile bağımsızlığını ilan ettiler. Söz konusu post-kolonyal devletlerde de elitler de Vestfalyan sistemin ilkelerini benimsediler. Böylece Vestfalyan devletler sistemi oldukça eski bir rakibi yani Darul İslam düzen tasavvurunu ortadan kaldırdı.

Lakin 1980'lerde ve 1990'larda uluslararası ilişkilerde yaşanan gelişmeler Darul İslam düzen tasavvurunun yeniden dirilişine sahne olmuştur. Ancak bu sefer Darul İslam'ı savunanlar devlet adamları değil devlet niteliği olmayan radikalterörist örgütler olmuştur. El Kaide, Taliban, Boko Haram ve IŞiD gibi terörist örgütler Darul İslam düzen tasavvurunu yeniden gündeme taşıdılar. Batı'da akademisyenler genellikle söz konusu örgütler ile tarihte kendilerini İslam devleti olarak niteleyen devletleri aynı kefeye koymaktadır. Hatta Mısır'daki Müslüman Kardeşler, Pakistan'da İslam Cemaati ve Türkiye'de Milli Görüş hareketini de söz konusu köktenci terör örgütleri ile aynı kefeye koymaktadırlar (Lewis, 2003 ve 2011; Kissinger, 2016). Söz konusu analizlerde Darul İslam düzen tasavvurunu benimseyen her devlet ve örgüt aynı başlık altında analiz edilmektedir. Böyle bir analizin ihmal ettiği veya gözden kaçırdığı bir durum vardır. Tarihteki İslam devletleri ve Müslüman kardeşler gibi örgütlerin Darul İslam tasavvuru ile radikal örgütlerin Darul İslam'ı arasında oldukça büyük bir fark vardır. Bu farkı yaratan ise radikal örgütlerin Uluslararası Hukukta savaşın sürdürülmesine ilişkin kuralları (jus in bello) hiçe saydığı gibi Kuran'da jus in belloya ilişkin ayetleri de bir şekilde hükümsüz kılmasıdır. Çalışmanın bundan sonraki bölümünün temel argümanı bu olacaktır. Söz konusu argümanı ele almadan önce terörizm ve küresel terörizm kavramlarını açıklamak gerekmektedir. Çünkü bu kavramların gelişi güzel bir şekilde ve bir dış politika söylemi olarak kullanılması konuyu içinden çıkılmaz bir hale getirmektedir.

\section{TERÖRİZM VE KÜRESEL TERÖRIZM KAVRAMLARI}

Terörizm olgusu ile ilgilenen devasa bir literatür olmasına rağmen terörizm kavramına ilişkin belirli bir tanımda uzlaşıldığını söylemek zordur. Charles Kegley'e göre, özellikle politikacılar günümüzde küresel terörizmin karakteri, nedenleri ve nasıl önleneceği konusunda fikir anlaşmazlığı içindedirler (Kegley, 2003: 7). Tanım soruna dikkat çeken bir diğer akademisyen BrianJenkins'tir. Bu çalışmada Jenkins'in terörizm ve uluslararası terörizm kavramları benimsendiği için onun yaklaşımı özetlenerek kavramsal çerçeve ele alınacaktır.Jenkins, terörizme ilişkin her tartışmanın er ya da geç kavram bataklığına döndüğüne vurgu yapmaktadır. Jenkins, terörizme ilişkin kendi tanımını yapmadan 
önce kelime bataklığı diye nitelediği duruma ilişkin çeşitli sorular sormaktadır: Terörizmin sıradan bir suç fiilinden ne farkı vardır? Siyasi saikli her şiddet terörizm midir? Terörizm gerilla savaşı ile eş anlamlı mıdır veya bir hükümete darbe yapmaya çalışanlar terörist midir? Hükümetler de terörist olabilirler mi? Bomba yüklü bir araçla büyükelçiliğe girip patlatmak ile bir şehri havadan bombalamak arasındaki fark nedir? Jenkins'in esas sorusu ise şudur: Terörizm olgusu hakkında kullanışlı tanımları nasıl yapacağı? (Jenkins, 2003: 16).

Terörizm, sosyal ve politik değişim yaratmayı hedefleyen korku ve panik ortamı yaratacak şekilde planlanmış şiddet veya şiddet kullanma tehdididir. Terörizm, klasik suç yöntemleri olan adam kaçırma, kundakçılık ve patlayıcı maddeler kullanmayı içeren fiillerden oluşmaktadır. Fakat geleneksel suçlardan ayrıldığı bir niteliği vardır. Terörizm, örgütlü bir toplumda kasıtlı olarak panik, düzensizlik ve korku yaratmayı amaçlayarak gerçekleştirilir (Jenkins, 2003: 16). Günümüzde terörizm kavramı pejoratif bir anlama sahiptir. Ancak 20. yüzyılın başına kadar terörizmin böyle olumsuz bir anlamı yoktu. 1880'lerde Çarlık Rusya'sında başlayan anarşist terörizm dalgasında teröristler kendilerini terörist olarak nitelemekteydiler. Kökenlerini Fransız devrimine hatta Haşhaşilere dayandırmaktaydılar. Kişisel menfaatleri için değil toplumun genelinin iyiliği için söz konusu siyasi suikastları gerçekleştirdiğini savunmuşlardır. Terörizm kavramı pejoratif niteliğini, de-kolonizasyon süreci sırasında bağımsızlık elde etmek için terörizme başvurulduğu dönemde kazanmıştır. Kolonyal devletler söz konusu fiilleri terörizm olarak nitelemiş ve böylece bağımsızlık elde etmek isteyen hareketleri gayri meşrulaştırmaya çalışmışlardır Söz konusu gruplar ise kendilerini terörist yerine özgürlük savaşçısı olarak nitelemişlerdir. (Rapoport, 2003: 39-41).

Birleşmiş Milletlere (BM) yaptığı bir konuşmada Yaser Arafat, haklı bir dava için savaşanların terörist olmadığını iddia etmiştir. Jenkins'e göre Arafat'ın ifadesini kabul edersek yani terörizm tanımına uğruna mücadele edilen davanın haklı mı olup olmadığını dâhil edersek terörizme ilişkin tanım sorunu daha karmaşık bir hale gelecektir. Çünkü dünya üzerinde aynı davaya ilişkin birbiriyle tamamen zit görüşler mutlaka vardır. Günümüzde terörizm, korku yaratma saikiylegerçekleştirilmemiş pek çok şiddet olayını da içerecek şekilde fark gözetilmeksizin kullanılan popüler bir kavram haline gelmiştir. İnsanları korkutma (terrorize) saiki ile gerçekleştirilmiş fiiller ve insanları sadece ürkütmek (terrify) için gerçekleştirilmiş fiiller arasında bir ayrım yapmak gereklidir. Haydutlar büyük bir yerleşim yerindeki halkı ürkütebilirler. Fakat bu korku, haydutların eyleminin yan sonucudur. Haydutların maksatları söz konusu insanların cüzdanları veya saatleridir, insanları korkutmak değil (Jenkins, 2003: 16-17).

Terörizmi tanımlamada yaşanan zorluk, "birinin teröristi diğerinin özgürlük savaşçısı"şeklinde bir klişeye yol açmıştır. Jenkins'e göre bu ifade, terörizme ilişkin nesnel bir tanımının olmadığını ve çatışmaların nasıl yürütüleceğine dair evrensel standartların olmadığını ima etmektedir. Ancak Jenkins'e göre, medeni toplumlar suç türlerine ilişkin kanunlar yapmışlardır. Cinayet, adam kaçırma, ölümle tehdit etme gibi suçlar her devletin ceza kanunlarında bulunmaktadır. İnsan öldürme gibi fiillerin savaş zamanında yasal olarak ihlal edildiği doğrudur. Ancak uluslararası hukukta bu durum "hukuki savaşçılar" (lawfulcombatants) şeklinde düzenlenmektedir. Teröristler suçlu (criminal) olmadıklarını fakat asker olduklarını ve böylece olağan (ordinary) hukuk kurallarını çiğneyebileceklerini iddia etmektedirler. Fakat savaşta bile bazı taktiklerin ve belirli silahların 
kullanılmasını hukuk dışı yapan kurallar vardır. Savaş usulü hukukuna göre, savaşla ilgisi olmayan siviller (noncombatants) kasıtlı saldırılardan bağışıktırlar ve savaşta geçerli bir hedef değillerdir. Savaşta esir alınanlara şiddet uygulamak yasaklanmıştır. Savaş usulü hukuku savaşın taraflarını ve tarafsız bölgeleri belirler. Bu kurallar bazen ihlal edilir ama ihlali gerçekleştirenler savaş suçlusu olurlar. İhlaller hiç bir şekildekuralların geçerliliğini zayıflatamaz (Jenkins, 2003: 17). Bu bağlamda terörizme ilişkin vurgulanması gereken bir diğer husus, terörizmin hedeflerinin geleneksel savaştaki gibi olmadığıdır. Geleneksel savaşlarda hedefler düşman bölgesini ele geçirmek ve düşmanı yok etmek gibi araçsaldır (instrumental). Terörizmin hedefleri ise semboliktir. Terörizmin geleneksel savaşı sürdürme kapasitesi olmadığ 1 için sembolik eylemlerle insanları korkutmak ve bu korku öğrenilmiş ise tehditler ile insanları korkutarak siyasi amaçlarını gerçekleştirmek için insanları manipüle etmeye çalışırlar. Böylece maksatlarını gerçekleştireceklerine yani kitlenin politik davranışlarını değiştireceklerine inanırlar. Bu yüzden teröristler günümüzde masum ve sivil insanları da hedef almaktadırlar (Jenkins, 2003: 21-22).

Jenkins'e göre terörizm, faillerin kimliğine veya davalarının haklılığına bakarak değil, eylemin niteliğine bakılarak objektif bir şekilde tanımlanabilir. Jenkins, bu kriterin terörizm kavramına ilişkin tüm belirsizliği ortadan kaldırmasa da bize bir çerçeve sağlayacağını ve bazı sorulara cevap vereceğini ifade etmektedir. Terörizm, sıradan suçlardan politik bir amacı olması bağlamında farklıdır. Sıradan bir banka soyguncusu ve eski ABD Başkanı Reagan'ı vuran adam terörist değildir. Aynı şekilde politik saiklerle işlenmiş her şiddet de terörizm değildir. Amerikan Devrimindeki gönüllü askerler ve Orta Amerika'daki isyancıların da politik hedefleri vardır. Fakat bu durum onları otomatikman terörist yapmaz. Terörizm gerilla savaşı ile veya herhangi bir savaş türü ile eş anlamlı değildir. Terörizm ayrıca bir hükümeti devirmeye çalışan kişilerin eylemini münhasır olarak ifade etmek için de kullanilamaz (Jenkins, 2003: 17-18).

Jenkins'e göre uluslararası terörizm, açık uluslararası sonuçları olan terörist eylemlerdir. Bu eylemler, terörist grubun kendi ülkesinden çıkıp bir başka ülkede hedeflerine saldırması veya kendi ülkesinde yabancı devletle ilişkili kurbanları (diplomatlar, söz konusu devletin şirketleri veya havayolu şirketleri gibi uluslararası ticari kuruluşları) içermektedir. Uluslararası veya daha popüler adıyla küresel terörizm kavramı, bir ülkede sadece kendi hükümetine karşı faaliyet gösteren terörist grupları veya vatandaşlarına karşı terörizm uygulayan devletleri kapsamamaktadır. Mesela, İrlandalı teröristlerin Belfast'ta diğer İrlandalıları bombayla yok etmesi uluslararası terörizm olarak nitelenmeyecektir. Kısaca, uluslararası terörizm kavramında ölçüt olarak terörist eylemin uluslararası alana yayılıp yayılmadığı dikkate alınmıştır (Jenkins, 2003: 18). Küresel terörist örgütler 1990'lardan itibaren uluslararası gündemi işgal etmeye başlamıştır. Farklı dinlerden köktenci örgütler de eylemlerde bulunmuştur ancak dikkat çekici eylemler çoğunlukla İslam'ı bir söylem olarak kullananradikal örgütler tarafından gerçekleştirilmiştir.

\section{5. İKİ SISTEMİN ÇATIŞMASI VE RADİKAL ÖRGÜTLER}

Soğuk Savaşın sona ermesi ile dünyanın daha barışçıl bir yer haline geleceğine ilişkin beklentilerin Güneydoğu Avrupa'da, Ortadoğu'da ve Afrika'da yaşanan iç savaşlar ve katliamlara bakıldığında gerçekleşmediği görülmektedir. Bosna ve Ruanda'da yüz binlerce insanın öldürüldüğü 
katliamlar yaşanmıştır. 1990'lardan günümüze post-kolonyal devletler iç savaşlarla ve krizlerle boğuşmaktadır. Literatürde bu devletleri tanımlamak için pek çok sıfat kullanılmaktadır: Çökmüş (collapsed), başarısız (failed), devletimsi (quasi-state) ve kırılgan (fragile) (Miiliken ve Krause, 2012; Eriksen, 2011). Söz konusu devletlerin ortak özellikleri ise ülkelerinin bir bölümünde veya tamamında meşru şiddet tekelini kaybetmiş olmalarıdır. Bu durum, çoğunluğunu Müslümanların oluşturduğu post-kolonyal devletler için de geçerlidir. Çoğunluğunu Müslümanların oluşturduğu devletlerde İslam'ı bir araç olarak kullanan uluslararası terör örgütlerinin gittikçe yaygınlaşması ve faaliyetlerini sıklaştırması uluslararası gündemi işgal etmeye başlamıştır. El Kaide'nin 11 Eylül 2001'de kaçırdığı uçaklarla New York'taki Dünya Ticaret Merkezi Kulelerini yok etmesi ile söz konusu terör örgütlerine ilişkin akademik çalışmalar tavan yapmıştır.

El Kaide, Taliban, Hamas, Hizbullah, Boko Haram ve IŞìD gibi radikal örgütlerin hangi saiklerledoğrudan masumları da hedef alan şiddet eylemlerini gerçekleştirdiğini, amaçlarının ne olduğunu, nasıl eleman topladıklarına (recruitment) dair çeşitli görüşler ortaya atılmıştır. Bir kısım uzman, çoğunluğunu Müslümanların oluşturduğu devletlerde yaşanan sosyo-ekonomik ve siyasi krizler ile küresel terörizm olgusunu açıklamaya çalışmaktadır. Çoğunluğu oluşturan bir diğer grup ise küresel terörizmi açıklamaya çalışırken söz konusu örgütlerin dünya görüşünü yani Darul İslam kavramını odağa almaktadır. Çoğunluğunu Müslümanların oluşturduğu toplumlarda sosyo-ekonomik sorunlara yüzeysel olarak da yer veren bu yaklaşıma göre küresel terörizmin esas nedeniDarul İslam düzen tasavvurunu benimsemiş olmalarıdır. Henry Kissinger ve Bernard Lewis gibi akademisyenler, dini saikli terörizmi ele aldığı analizlerinde söz konusu kavramın varsayımlarını ve tarihsel gelişimini ana tema olarak benimsemektedirler. Analizlerinde Darul İslam kavramını ve bu kavramı savunan devletlerin 14 asırlık serüvenini özetledikten sonra 1990 sonrası yaygınlaşan radikal örgütler hakkında bir sonuca varırlar. Sonuç ise, Darul İslam-DarulHarb düzen tasavvuru küresel terörizmin esas nedenidir (Kissinger, 2016: 111-163; Lewis, 2003: 194-201 ve 2011: 109-136). Analizlerinde doğrudan söylemeseler de El Kaide, Hamas, Hizbullah, Taliban, Boko Haram ve IŞİD gibi radikal örgütler ile tarihte kendisini İslam devleti olarak niteleyen Emeviler, Abbasiler, Osmanlı İmparatorluğu gibi devletleri aynı kefeye koymaktadırlar. Hatta Kissinger, 20. Yüzyılda Müslümanların içinde bulunduğu kötü durumdan çıkmalarına ilişkin analizler yapan Hasan el-Benna ve Seyyid Kutup (2014) ile Müslüman Kardeşleri de Darul İslam sistemini benimsedikleri için küresel terörist gruplarla özdeşleştirmektedir (Kissinger, 2016: 134-138). Kissinger'ın perspektifinden bakılırsa Türkiye'de Necmettin Erbakan'ın temellerini attığı Milli Görüş hareketi ve Pakistan'da Mevdudi'nin kurduğu İslam Cemaati hareketi de kaçınılmaz olarak terörist örgütler ile aynı kefeye konmaktadır. Kissinger ve Lewis'inbakış açısınınBatılı literatürde hâkim olan anlayışı temsil ettiği söylenebilir. Ancak bu bakış açısı hem eksik ve hatalı hem de aşırı genelleyici bir yaklaşımı temsil etmektedir.

İlk olarak, küresel terörizmi Darul İslam sistemini açıklayarak analize başlayanlar yerinde bir tercih yapmaktadırlar. Ancak bu sistemi benimseyenlerin Darulİslamı gerçekleştirmek için aynı yöntemleri kullanmadıklarını görmezden gelmektedirler. Aynı dünya tasavvurunu benimsedikleri için Osmanlı Devletini ve IŞİD'i aynı kefeye koymak oldukça tutarsız bir analizdir. BrianJenkins'in de ifade ettiği gibi, bir şiddet eylemini objektif bir biçimde terörizm olarak nitelemek için faillerin 
kimliğine ve amaçlarının doğasına değil eylemlerinin niteliğine bakmak gerekmektedir. Aksi takdirde yapılan analizler içinden çıkılmaz bir hal alacaktır. 1973 yılında toplanan BM Terörizm Alt Komitesi'ndeuluslararası terörizmin tanımlanmasına dair yapılan tartışmalar bu duruma iyi bir örnektir. Söz konusu toplantıda Bağlantısızlar Hareketine üye devletlere göre terörizm kolonyal faaliyetlerde bulunan devletlerin uygulamalarıdır. Batılı devletler ise terörizmi, mevcut statükoyu değiştirenlerin fiilleri olarak tanımlamıştır (UN Report, 1973). Yani iki taraf da birbirini terörist olarak nitelemiştir. Aynı çıkmaz durum günümüzde yaşanmaktadır.Darul İslam sistemini savunlar Batılı devletleri terörist olarak nitelerken, Batılı devletler ve akademisyenler deDarul İslam sistemini savunanları terörist olarak nitelemektedir.

İkinci olarak, Jenkins'in terörizm kavramında belirleyici olan faillerin eylemlerinin niteliğidir. Terörizm olarak nitelenen eylemlerde faillerin eylemlerini sınırlayan hiçbir kanun veya kural yoktur. Yukarıda da belirtildiği gibi uluslararası hukukta haklı bir gerekçeye dayansın veya dayanmasın savaşların nasıl sürdürüleceğine dair evrensel kurallar vardır. Bu kurallar uluslararası bir çatışmada yer alan savaşçıları (combatants) ve savaşçı olmayanları birbirinden ayırmıştır. Uluslararası hukuk hem savaşçılar hem de savaşçı olmayanlar hakkında savaş sırasında uyulması gerekli kurallar içermektedir. Örnek olarak, savaşçı statüsüne sahip olan kişiler karşı tarafın esiri olduklarında savaş tutsağı olarak işlem görmelidir. Bu bağlamda savaş esirlerine işkence yapılması, şiddet uygulanması ve öldürülmesi yasaklanmış eylemler arasındadır. Çatışmalarda savaş̧̧ı olmayanlar statüsüne giren sivillerin kasıtlı olarak hedef alınması ve saldırılması yasaktır. Uluslararası hukuka göre uluslararası bir çatışmada taraflar sınırsız bir şekilde savaş araç ve yöntemlerini seçme hakkına sahip değildir, yani savaşta kullanılacak araç ve yöntemlere ilişkin olarak da bir sınırlama söz konusudur. Uluslararası çatışmalarda sivil hedeflerin, savaş dışı kalmış kişilerin ve yerlerin hedef alınmasıyasaklanmıştır. Kimyasal silahlar, mayınlar ve lav silahı, napalm gibi bazı yakıcı silahların kullanılmasının yasaklanması da bu sınırlamalara örnek gösterilebilir (Pazarcı, 2009: 572-604).IŞID, El Kaide, Boko Haram gibi İslam'ı bir söylem olarak kullanan radikal örgütleri terörist yapan; hiçbir ahlaki, hukuki ve insani ilke kural vb. ile sınırlandırılmamış olmalarıdır. Saldırılarını savaşçı ve savaşçı olmayan ayrımı gözetmeksizin ve her türlü araç ve yöntemi kullanarak gerçekleştirmektedirler. Söz konusu örgütler İslam'ı bir söylem olarak dillerinden hiç düşürmemelerine rağmen Kuran'da jus in belloya ilişkin hükümleri bile görmezden gelmektedirler. Bakara Suresi 190. ayette ${ }^{5}$ keyfi bir şekilde şiddete başvurmak sınırlandırılmıştır: "Sizinle savaşanlarla ALLAH yolunda savaşın. Saldırgan olmayın. ALLAH saldırganları sevmez." (Yüksel, 2014: 50). Benzer sınırlamalar diğer Kuran ayetlerinde de vurgulanmaktadır. Maide Suresi 5. Ayet: "... Kim, cinayet işlememiş veya yeryüzünde bozgunculuk yapmamış bir kişiyi öldürürse tüm insanları öldürmüş gibidir. Kim de o canı yaşatırsa, bütün insanları yaşatmış gibi olur..."Enfal Suresi 61. ayet: "Onlar barışa eğilim gösterirlerse sen de ona eğilim göster..." Görüldüğü gibi Kuran da savaş başladıktan sonra savaşçıların istediği gibi insanları öldürmesine ve istediği savaş araç ve yöntemlerini belirlemesini sınırlandırmaktadır (Taslaman, 2016:

\footnotetext{
${ }^{5}$ Edip Yüksel'in bu ayeti çevirisinde "Saldırgan olmayın. ALLAH saldırganları sevmez." cümlelerini Elmalılı Hamdi Yazır, "... haksız saldırıda bulunmayın, çünkü Allah, haksız saldırıda bulunanları sevmez" şeklinde çevirmiştir. Mevdudi'nin başını çektiği bir grup çevirmen ise aşırı gitmeyin/ haddi aşmayın çünkü Allah aşırı gidenleri/ haddi aşanları sevmez şeklinde çevirmektedir (Kuranmeali.org, 2016).
} 
50-52). Kuran ayetlerinin yanı sıra Hz. Muhammed'in de jus in belloya ilişkin söylediği sözler vardır. Söz konusu hadislerde savaş sırasında çocukları, kadınları, yaşlıları ve savaşamayacak durumda olanları öldürmeyin, hatta tarım alanlarını talan etmeyin şeklinde sınırlandırıcı ifadeler dikkat çekmektedir. ${ }^{6}$

Tarihteki İslam devletleri ve günümüzde onların dünya tasavvurunu benimseyen Müslüman kardeşler, İslam Cemaati, Milli Görüş gibi dini temelli hareketler ile söz konusu terörist örgütler bu bağlamda aynı kefeye konulamaz. Çünkü yukarıda da belirtildiği gibi ilk grupta yer alanları cinayet ve adam kaçırma gibi tüm devletlerin iç hukukunda yasaklanmış evrensel ilkeler ve jus in belloya ilişkin hem uluslararası hukuk hem de Kuran ayetleri sınırlandırmaktadır. İkinci grupta yer alan El Kaide, Taliban, Boko Haram ve IŞiD gibi terörist örgütleri sınırlandıran hiçbir ahlaki, dini, hukuki kural yoktur. Bu duruma örnek olarak El Kaide'nin Dünya Ticaret Merkezinde 3.000 masum insanı öldürmesi, BokoHaram'ın Nijerya'da 200 kız çocuğunu kaçırması, Taliban'ın kendi inançlarına uygun davranmayan Müslümanlara işkence etmesi ve onları idam etmesi ve IŞiD'in yakaladığı esirlerin kafalarını kesip sosyal medyada propaganda yapması gösterilebilir.

\section{SONUÇ}

Kuran, meşru müdafaa durumları hariç şiddete başvurmaya müsaade etmemektedir. Hz. Muhammed ve ilk dört halife dönemlerinde yapılan savaşlar Müslümanlar için yaşamlarını ve inançlarını korumak üzerine verilmiş savaşlardır. Bizans ve Sasani İmparatorluğu İslamiyet'in ortaya çıktığı dönemde birbirleri ile uzun yıllardır savaş içindeydi. Uzun süren bu savaşlarda can kayıpları ve maliyetler halkın tepkisini çekmeye başlamıştı. Bizans ve Sasani yönetimleri söz konusu tepkiyi azaltmak ve halkı savaşa teşvik etmek için Hristiyanlık ve Zerdüştlük dinini araçsal olarak kullanmaya başladılar. Dinin bir baskı unsuru haline geldiği Ortadoğu ve çevresinde halklar için İslam'ın toplumsal adalet ve eşitliğe yönelik mesajlarının oldukça yoğun bir ilgiyle karşılaşması kaçınılmazdı. Ali Şeriati'ye göre, İslam'ın 50-60 yıl gibi kısa bir sürede Arap Yarımadası, Ortadoğu ve Kuzey Afrika'ya nüfuz etmesi söz konusu bölgelerin sosyo-ekonomik ve siyasi durumu ile yakından ilgilidir (Şeriati, 2013a ve 2013b). Bizans ve Sasani yöneticilerinin kendileri için tehdit haline gelen İslamiyet'i yok etmek için harekete geçmeleri Medine merkezli İslam İmparatorluğu ile Bizans ve Sasani İmparatorlukları arasında savaşlara yol açmıştır. Kısaca İslamiyet'in ilk 50-60 yılı Müslüman toplumun kendisine yönelik saldırılara karşı varoluş mücadelesi verdiği dönemdir. Kuran da böyle bir durumda Müslümanlara savaşmaya cevaz vermiştir. Ancak Emeviler dönemi ile birlikte savaşlar sadece meşru müdafaa bağlamında yapılmamış, politik, stratejik ekonomik vb. kaygılarla da çeşitli savaşlar gerçekleştirilmiştir. Bazı İslam hukukçuları Kuran'ın sadece meşru müdafaa durumunda savaşa başvurulması şeklindeki kısıtlamasını esnetmek için nesih kavramını Kuran ayetleri arasında da uygulamışlardır. Bu uygulama ise dünyanın Darul İslam ve DarulHarb şeklinde ikiye ayrıldığı bir sistemi ortaya çıkarmıştır. Darul İslam ve DarulHarb kavramları Kuran'da ve Hadislerde yer almayan ifadelerdir ve İslam hukukçularının uluslararası ilişkiler teorisi olarak da nitelenebilir. Emevilerdönemi ile başlayan bu eğilim Osmanlı İmparatorluğu dâhilhalkının çoğunluğu Müslüman olan devletler tarafindan benimsenmiş bir dünya tasavvuru haline gelmiştir.

${ }^{6}$ Bahsi geçen hadisler için bakınız, (Kutub, 2012: 156-159). 
Müslüman yöneticiler dünyanın İslam hukukunun uygulama alanı haline gelmesiyle daha adil ve barışçıl bir dünyanın ortaya çıkacağına inanmışlardır. Yapılan savaşlarda toprak, ganimet vb. maddi çıkarlar elde etmek arzusu da mutlaka olmuştur, ama idealist bir dünya tasavvurunu benimsedikleri söylemlerine ve davranışlarına yansımıştır. Kuran'da toplumsal adalete ve eşitliğe yönelik ayetler böyle idealist bir sistem benimsemelerini gereklilik haline getirmiştir. Bu bağlamda günümüz Müslüman toplumlarının içinde bulunduğu sosyo-ekonomik ve siyasi krizlerde İslami söylemleri vurgulayan çeşitli akımların bu kadar çok ilgi çekmesi ve taraftar toplaması şaşılacak bir durum değildir. Çünkü yukarıda da ifade edildiği gibi İslamiyet'in ortaya çıktığı 7. yüzyılda da Pakistan'dan Fas'a kadar olan bölge benzer bir istikrarsızlık içindeydi. İnsanların zor zamanlarda içinde bulunduğu durumdan kendilerini kurtaracak çareler aramaları doğaldır. $\mathrm{Bu}$ bağlamda çoğunluğunu Müslümanların oluşturduğu ulus devletlerde 1990 sonrası yaşanan sosyo-ekonomik ve siyasi krizlerde Darul İslam düzen tasavvurunu savunan akımlar gittikçe rağbet görmektedir.

Hint alt kıtasından Fas'a kadar olan hatta yer alan devletler bağımsızlıklarını 20. yüzyılın ortalarında elde etmişlerdir. Söz konusu bölgede Vestfalyan düzeni benimsemiş ve kendi ulus devletlerini kurmak isteyen elitler, kolonici devletlere yönelik bağımsızlık mücadelesi vermişlerdir.Ulusal liderler sömürgeci düzenin, halklarına verdiği zararları ortaya koyup ulus devletlerini kurmaları ile bu sömürü ilişkisinden kurtulacaklarını vaat etmişlerdir. Refah içinde bir gelecek vaadi diğer kolonyal toplumlar için olduğu gibi çoğunluğunu Müslümanların oluşturduğu toplumlar için de cazip gelmiştir. Ancak ulusal elitler çeşitli nedenlerden ötürü vaatlerini yerine getirememişlerdir. 1990'lardan günümüze Pakistan'dan Fas'a kadar olan kuşakta çoğunluğunu Müslümanların oluşturduğu devletler iç savaşlar, sosyo-ekonomik ve siyasi krizler ile boğuşmaktadır. Literatürde başarısız, çökmüş, kırılgan gibi çeşitli sıfatlar ile nitelenen devletler Darul İslam düzen tasavvurunu benimseyen elitler için bir firsat yaratırken Vestfalyan devletler sistemi ve ABD'nin II. Dünya Savaş sonrası kurduğu küresel düzen için bir tehdit haline gelmiştir.

Çoğunluğunu Müslümanların oluşturduğu toplumlar Batı'daki gibi Rönesans ve Reform'u yaşamamışlardır. Dolayısıyla Vestfalyan sistemin temel ilkeleri olan devletlerin egemen eşitliği, iç işlerine karışmama ve bu ilkelerin sonucu olarak devletlerin toprak bütünlügünün korunması, uluslararası sistemde devletlerin üstünde Papalık dâhil hiçbir üst otoritenin olmadığı bir sistem pek bir anlam ifade etmemektedir. Çoğunluğunu Müslümanların oluşturduğu toplumlarda insanlar için ulus devletin bir amaç değil bir araç olduğu söylenebilir. Müslümanların yaşadıkları sorunlara bir çözüm bulamayan ulus devletleri ve devletlerin temel aktör olduğu Vestfalyan sistemi sorgulamaları şaşılacak bir durum değildir. Misır'da Hasan el-Benna (Kutup vd., 2014) ve SeyyidKutub'un (2014) görüşlerinin şekillendirdiği Müslüman Kardeşler hareketi, Pakistan'da Mevdudi'nin (2014) fikri temellerini attığ1 İslam Cemaati ve Türkiye'de Necmettin Erbakan'ın kurduğu Milli Görüş gibi küresel düzeni eleştiren hareketlerin gittikçe rağbet görmesi söz konusu durum tespitini örneklemektedir. ${ }^{7}$

Ancak Batılı devletler için esas tehdidi,1990'lardan sonra faaliyetlerini artıran küresel terörist örgütler oluşturmaktadır. El Kaide, Taliban, Boko Haram ve IŞİD gibi küresel terör örgütlerini sistem

\footnotetext{
${ }^{7}$ Söz konusu örgütler hakkında detaylı bir çalışma için bak. (Mangır, 2011).
} 
için tehdit haline getiren unsur bu örgütlerin de Müslümanlara kurtuluş reçetesi olarak Darul İslam düzen tasavvurunu sunmalarıdır. Bu nedenle Batılı analizciler Darul İslam'ı savunan herkesi aynı kefeye koymaktadır. Ancak ortada belirgin bir fark vardır. Radikal örgütler ile Darul İslam'1 benimseyen diğeryapılar (gerek devletler olsun gerekse de siyasi parti, dernek gibi oluşumlar)arasında Darul İslam'ın nasıl kurulacăğ konusunda derin farklılıklar vardır. Günümüzde 1lımlı İslamcılar ve köktenci (fundementalist) İslamcılar diye bir ayrım yapılması da seçilen yöntem ve araç farklılıklarının bir sonucudur. Radikal örgütleri amaçları doğrultusunda sınırlayan hiçbir dini, hukuki ve insani kural bulunmamaktadır. Sivillerin olduğu bir binayı, sıradan insanların alışveriş yaptığı bir pazar yerini ya da herhangi bir inanca ait ibadet yerini bombalamak ile nihai hedeflerine ulaşacaklarını varsaymaktadırlar. Bu nedenle Osmanlı İmparatorluğu gibi tarihteki İslam devletlerini ve günümüzde Darul İslam'ı benimseyen Müslüman Kardeşler gibi hareketleri El Kaide, İşiD gibi terörist örgütler ile sadece aynı dünya görüşünü benimsiyorlar diye aynı kefeye koymak oldukça tehlike bir yaklaşımdır.

Tarihte olduğu gibi günümüzde de İslam'ı benimseyen toplumları ve grupları monolitik (yekpare) olarak düşünemeyiz. İslam'ın Sünnilik ve Şiilik gibi iki farklı ana kolu olduğu gibi, her kolun içinde birbirinden oldukça farklı öğretilere sahip olan alt mezhepler de bulunmaktadır. Bu duruma karşın 1990'lardan itibaren özellikle SamuelHuntington'ın (Huntington, 2014: 23-51) Medeniyetler Çatışması tezi ile birlikte başlayan bir eğilim günümüzde de sürmektedir. Huntington, birbiriyle anlaşmazlık içinde olan Müslüman toplumları bile İslam medeniyeti altında bir grupta toplamakta ve bu medeniyetin kendine has değerleri olduğu varsayımından yola çıkarak Batı medeniyeti ile çatışma içine gireceğini iddia etmektedir. Bernard Lewis ve Henry Kissinger gibi popüler akademisyenler de Darul İslam dünya tasavvurunu benimsedikleri için Müslümanların hepsini türdeşmiş gibi nitelemektedir. Söz konusu toptancı bakış açısının yol açacağı bazı olumsuz durumlar olduğu ifade edilebilir. Her şeyden önce El Kaide, İŞiD gibi terörist örgütler ile diğer Müslümanları aynı kefeye koymak, 1lımlı diye nitelendirilen Müslümanların da radikalleştirilmesi ile sonuçlanabilir. Ki buda radikal örgütlerin istediği bir durumdur. El Kaide'nin Dünya Ticaret Merkezini yok etmesi ve binlerce masum insanı öldürmesi dünya genelinde özellikle de Batılı ülkelerde Müslümanlara potansiyel terörist gözüyle bakılmasına yol açmıştır. Müslüman oldukları için toplumsal baskıya ve hatta şiddete maruz kalmışlardır. Müslümanlara yönelik bu olumsuz eğilim günümüzde İslamafobiya olarak literatüre geçmiştir. İslamafobiyanın gittikçe yaygınlaşması Müslümanların radikalleşmesi riskini doğurmaktadır. Dünya genelinde iki milyara yaklaşan bir Müslüman nüfus olduğu dikkate alınırsa böyle bir riskin sadece Müslümanlar için değil tüm dünya için felaket anlamına geleceği iddia edilebilir. Kısaca, Emre Kongar (2016: 43-69) ve Caner Taslaman'ın (2016: 68-69) da ifade ettiği gibi Huntington'ın savunduğu medeniyetler çatışması tezi benzeri toptancı yaklaşımlar aslında medeniyetler çatışması için bir zemin hazırlamaktadır.

Özetle, Batılıların tabiriyle 1lımlı (moderate) İslamcılar ve köktenci (fundamentalist) İslamcılar arasındaki fark ikinci grupta yer alanların Darul İslam'ı gerçekleştirmek için her türlü araç ve yöntemi kullanmasıdır. Jenkins'in de ifade ettiği gibi, bir davanın haklı olup olmadığı ve bu davayı savunanların niteliği bir grubu terörist yapmaz. Onları terörist yapan eylemlerinin niteliğidir. Kissinger'ın 1srarla olumsuzladığı Müslüman Kardeşler hareketi liderleri Muhammed Mursi askeri bir darbe ile iktidardan indirildiğinde terörizme başvurmak bir yana şiddete bile başvurmamıştır. Halk 
mitingleriyle ile darbe rejimini protesto etmişlerdir. Müslüman Kardeşler gibi mevcut düzen içinde iktidar arayan siyasi oluşumlara terörist muamelesi yapmak onların da IŞiD gibi radikalleşmelerine yol açma riski taşımaktadır. Toptancı bir bakış açısıyla Müslüman toplumları ele almak yerine her bir toplumun yaşadığı spesifiksosyo-ekonomik ve siyasi sorunlara eğilmek gerekmektedir. Aksi takdirde Pakistan'dan Fas'a bu geniş kuşak daha çok El Kaide'ler ve IŞiD'ler çıkarmaya müsait bir ortama dönüşmektedir. 


\section{KAYNAKÇA}

BAYINDIR, Abdülaziz (2014), Kur'an Işı̆̆ı̆ıda Doğru Bildiğimiz Yanlışlar (5. Bask1), İstanbul: Süleymaniye Vakfi Yayınları.

ERIKSEN, SteinSundstol (2011), ''StateFailure' in TheoryandPractice: TheIdea of theStateandtheContradictions of StateFormation", Review of International Studies, 37, 229-247.

GROSS,Leo (1948), "ThePeace of Westphalia, 1648-1948", TheAmericanJournal of International Law, 42 (1), 20-41.

HOBBES, Thomas (2013), Leviathan veya Bir Din ve DünyaDevletinin İçeriği, Biçimi ve Kudreti (12. Baskı), (Çeviren: Semih Lim), İstanbul: Yapı Kredi Yayınları.

HUNTINGTON, Samuel P. (2014), "Medeniyetler Çatışması mı?", içinde Samuel P.Huntingtonv.d.,Medeniyetler Çatışması, (derleyen) Murat Yılmaz, İstanbul: Vadi Yayınları.

JENKINS, Brian M. (2003), "International Terrorism: TheOther World War", içinde The New Global Terrorism: Characteristics, Causes, Controls (Editör: Charles W. Kegley), New Jersey: PrenticeHall, ss. 15-26.

KEGLEY, Charles W. (2003), "TheCharacteristics, Causes, andControls of the New Global Terrorism: An Introduction", içinde Charles W. Kegley (editör), The New Global Terrorism: Characteristics, Causes, Controls, New Jersey: PrenticeHall, ss. 1-14.

KİSSİNGER, Henry(2016), Dünya Düzeni (2. Basım), İstanbul: Boyner Yayınları.

KONGAR, Emre (2016), Küresel Terör ve Türkiye: Küreselleşme, Huntington, 11 Eylül, Etnikçi ve Mezhepçi Terör Kapanında Türkiye (14. Basım), İstanbul: Remzi Kitabevi.

KURANMEALİ.ORG (2016), "Bakara Suresi 190. ayet için Kuran Meallerini Kıyasla", http://www.kuranmeali.org/2/bakara_suresi/190.ayet/kurani_kerim_mealleri.aspx (Erişim Tarihi: 12.11.2016).

LEWIS, Bernard (2003), "TheRoots of MuslimRage", içinde Charles W. Kegley (editör), The New Global Terrorism: Characteristics, Causes, Controls, New Jersey: PrenticeHall, ss. 194-201.

LEWİS, Bernard (2011), İslam'ın Siyasal Söylemi (çeviren: Ünsal Oskay), Ankara: Phoenix Yayınevi.

MANGIR, Demet Şefika (2011), "İslamcı İdeoloji ve İslamcı Hareketler Ekseninde Ortadoğu", ICANAS 38. Uluslararası Asya ve Kuzey Afrika Çalışmaları Kongresi Bildiriler: Uluslararası İlişkiler, Ankara: Atatürk Kültür, Dil ve Tarih Yüksek Kurumu, ss. 1-26.

MEVDUDİ, Mevlana SeyyidEbu'l-A'la (2004), Tefhimu'l-Kur'an Meali, (Çeviren: Durmuş Bulgur), Konya: Yediveren Kitap. 
MEVDUDİ, Mevlana SeyyidEbu'l-A'la (2014), İslam Savaşçısının Ahlaki Stratejisi (çeviren: H. Hüseyin Y1lmaz), İstanbul: Özgü Yayınları.

MíLLIKEN, Jennifer andKrause, Keith (2002), "StateFailure, StateCollapse, andStateReconstruction: Concepts, LessonsandStrategies", Development andChange, 33 (5), 753-774.

UN REPORT (1973), "Report of the Ad Hoc Committee on International Terrorism", General Assembly OfficialRecords: 28 SessionSupplement No: 28 (A/9028), New York: United Nations.

ÖZEL, Ahmet (2012), "Klasik İslâm Devletler Hukukunda Ülke Kavramı ve Günümüzdeki Durum: İbnTeymiyye'nin Mardin Fetvası ile Benzeri Diğer Bazı Fetvalar", M.Ü. İlahiyat Fakültesi Dergisi, 43 (2), 41-64.

ÖZEL, Ahmet (2014), Darul İslam DarulHarb: İslam Hukukunda Ülke Kavramı (3. Bask1), İstanbul: İz Yayınc1lık.

ÖZTÜRK, Yaşar Nuri (2016), Kur'an-ı Kerim Meali (Türkçe Çevirisi), İstanbul: Yeni Boyut.

PAZARCI, Hüseyin (2009), Uluslararası Hukuk (8. Baskı), Ankara: Turhan Kitabevi.

POGGİ,Gianfranco (2012), Modern Devletin Gelişimi: Sosyolojik Bir Yaklaşım (6. Baskı), İstanbul: İstanbul Bilgi Üniversitesi Yayınları.

RAPOPORT, David C., "TheFourWaves of RebelTerrorandSeptember 11", içinde Charles W. Kegley (editör), The New Global Terrorism: Characteristics, Causes, Controls, New Jersey: PrenticeHall, ss. 36-52.

KUTUB,Seyyid (2012), İslam Davasının Stratejisi, İstanbul: Özgü Yayınları.

KUTUP, Seyyidvd. (2014), İslam'da Cihad, İstanbul: Özgü Yayınları.

ŞERİATI, Ali (2013a), Dinler Tarihi I, (çeviren: Ejder Okumuş),Ankara: Fecr Yayınları.

ŞERİATİ, Ali (2013b), Dinler Tarihi II, (çeviren: Ejder Okumuş),Ankara: Fecr Yayınları.

TASLAMAN, Caner (2016), 'Terör'ün ve 'Cihad'ın Retoriği: Felsefi ve Teolojik Değerlendirmeler, İstanbul: İstanbul Yayınevi.

YÜKSEL, Edip (2014), Mesaj: Kuran Çevirisi (12. Bask1), İstanbul: Ozan Yayınc1lık. 